\title{
Christelike etiek vanuit die perspektief van naasteliefde: Rudolf Bultmann en Stoïsynse etiek
}

\begin{tabular}{|c|c|}
\hline \multicolumn{2}{|c|}{$\begin{array}{l}\text { Author: } \\
\text { Andries G. van Aarde }\end{array}$} \\
\hline $\begin{array}{l}\text { Affiliation: } \\
{ }^{1} \text { Professor Em } \\
\text { Senior Resear } \\
\text { Unit for the A } \\
\text { of Scholarship } \\
\text { Pretoria, Sout }\end{array}$ & $\begin{array}{l}\text { eritus and } \\
\text { ch Fellow in the } \\
\text { dvancement } \\
\text {, University of } \\
\text { h Africa }\end{array}$ \\
\hline $\begin{array}{l}\text { Note: } \\
\text { This article wa } \\
\text { published in } \\
\text { Teologiese Tyc } \\
\text { (2014), 27-42 } \\
\text { 'Christelike eti } \\
\text { perspektief va } \\
\text { Rudolf Bultma } \\
\text { etiek'. It is rew } \\
\text { republished in } \\
\text { Studies/Theol } \\
\text { with the edito }\end{array}$ & $\begin{array}{l}\text { s first } \\
\text { lervormde } \\
\text { yskrif 2(3) } \\
\text { titled } \\
\text { itl vanuit die } \\
\text { n naasteliefde: } \\
\text { inn en Stoïsynse } \\
\text { lorked and } \\
\text { HTS Teologiese } \\
\text { ogical Studies } \\
\text { r's permission. }\end{array}$ \\
\hline $\begin{array}{l}\text { Corresponden } \\
\text { Andries van A }\end{array}$ & $\begin{array}{l}\text { ice to: } \\
\text { arde }\end{array}$ \\
\hline $\begin{array}{l}\text { Email: } \\
\text { andries.vanaa }\end{array}$ & rde@up.ac.za \\
\hline $\begin{array}{l}\text { Postal addres } \\
\text { Private Bag X2 } \\
0028 \text {, South A }\end{array}$ & $\begin{array}{l}\text { s: } \\
\text { 0, Hatfield } \\
\text { frica }\end{array}$ \\
\hline $\begin{array}{l}\text { Dates: } \\
\text { Received: } 26 \\
\text { Accepted: } 15 \\
\text { Published: } 15\end{array}$ & $\begin{array}{l}\text { Nov. } 2014 \\
\text { Feb. } 2015 \\
\text { June } 2015\end{array}$ \\
\hline $\begin{array}{l}\text { How to cite th } \\
\text { Van Aarde, A. } \\
\text { 'Christelike eti } \\
\text { perspektief va } \\
\text { Rudolf Bultma } \\
\text { etiek', HTS Teo } \\
\text { Studies/Theol } \\
71(3), \text { Art. \#28 } \\
\text { http://dx.doi. } \\
\text { hts.v71i3.287 }\end{array}$ & $\begin{array}{l}\text { is article: } \\
\text { G., 2015, } \\
\text { iek vanuit die } \\
\text { n naasteliefde: } \\
\text { Inn en Stoïsynse } \\
\text { logiese } \\
\text { ogical Studies } \\
370,12 \text { pages. } \\
\text { org/10.4102/ }\end{array}$ \\
\hline $\begin{array}{l}\text { Copyright: } \\
\text { C) 2015. The A } \\
\text { Licensee: AOS } \\
\text { OpenJournals } \\
\text { licensed unde } \\
\text { Commons Att } \\
\text { License. }\end{array}$ & $\begin{array}{l}\text { Authors. } \\
\text { IS } \\
\text { This work is } \\
r \text { the Creative } \\
\text { ribution }\end{array}$ \\
\hline 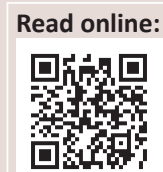 & $\begin{array}{l}\text { Scan this QR } \\
\text { code with your } \\
\text { smart phone or } \\
\text { mobile device } \\
\text { to read online. }\end{array}$ \\
\hline
\end{tabular}

Christian ethics from the perspective of neighbourly love: Rudolf Bultmann and Stoic ethics. This article consists of various sections. The first concerns a cultural-sensitive explanation of the meaning of the term 'neighbour'. The second exemplifies Rudolf Bultmann's understanding of the meaning of the love commandment which is found in the Jesus tradition and in the New Testament. This explanation represents a paraphrase of Bultmann's reflection on the notion 'neighbourly love' in Afrikaans. The article elaborates on Bultmann's interpretation by means of expanded exegetical comments. The article also endorses Bultmann's juxtaposition of Christian ethics with Greek Stoic ethics. This Greek heritage is described in an expanded way. The article discusses Bultmann's understanding of neighbourly love within the context of the core values of his hermeneutics. The results are made relevant for the present-day Christian ethical perspective on the adherence to the so-called natural law, applied to the South African sociopolitical situation.

\section{Prolegomenon}

Hierdie voorlesing ter ere van Rudolf Bultmann se geboorte 130 jaar gelede, op 20 Augustus 1884 in Wiefelstede (Großherzogtum Oldenburg, Duitsland), dra ek op aan my vriend, dr Christo van der Merwe. Ons vriendskap bestaan sedert ons gesamentlike studentetyd aan die Universiteit van Pretoria en is met diepgang voortgesit as jong buur predikante in ons eerste gemeentes in Johannesburg en Roodepoort, respektiewelik. Meer nog, Christo was die persoon wat saam met my my sieklike vader in koma in die Waterberg voor sy dood gaan groet het en dae daarna na die afsterf van my vader, Jan Christiaan van Aarde, hom in Vaalwater begrawe het. Christo het my akademiese reis en die motief agter die skryf van my boek Fatherless in Galilee: Jesus as Child of God (2001) eksistensieel verstaan. Dit is God se wil dat hy gedurende die laaste jare in sy aktiewe loopbaan voor en na sy emeritaat as predikant 'n akademiese kollega saam met my aan die Universiteit van Pretoria was, wat ek as 'n seën ag. Ek dra hierdie opstel oor naasteliefde op aan my vriend, Christo van der Merwe.

\section{Naasteliefde ${ }^{1}$}

Hoewel Franciskus van Assisi (1181/1182-1226) in die geskiedenis van die Christelike etiekdiskoers daarvoor bekend is dat sy verstaan van liefde neig om universeel en abstrak te wees sonder dat dit altyd noodwendig in die konkrete werklikheid toegepas is, ${ }^{2}$ vat die refrein van die kerklied 'Laat Heer u vrede deur my vloei' ['Make me a channel of your peace'] wat by Franciskus se etiek begin het, myns insiens Bultmann se verstaan van 'naasteliefde' besonder goed saam:

\footnotetext{
O Heer help my om altyd so te leef -

om ander hoër as myself te ag,

ja, om lief te hê - ander bo my self -

en ook eerder te gee as te verwag. ${ }^{3}$
}

Hierdie refrein stel dit sonder omhaal van woorde dat 'naasteliefde' as liefde 'soos vir jou self' op geen manier as selfdienende liefde verstaan kan word nie. Hierdie aksiomatiese uitspraak veronderstel egter nie dat die betekenis van die woord 'naaste' nie kultuursensitief verstaan behoort te word nie. In Israelse (oos-Mediterreense) konteks word 'n persoon se sosiale identiteit, rol en waarde bepaal deur die groep waarvan die persoon deel is (vgl. Malina \& Neyrey 1996: 151-201). Omgee vir die groep is omgee vir jouself; beskerming van jouself is die beskerming

\footnotetext{
1.Markus 12:29-31; Matteus 22:37-40; Lukas 10:27; Didache 1:2; ThomasEv 25:1-2; Barnabas 19:5; Levitikus 19:18 (LXX) (kyk Funk 1990:196-197).

2.Kyk onder andere Iriving Singer (2009:151) oor Nietzsche se kritiek op Franciskus.
}

3.Lied 284 in Liedboek van die kerk: Vir gebruik by die erediens en ander byeenkomste (2001), Afrikaanse weergawe van Jacques Louw (2001) van Franciskus van Assisi se 'Make me a channel of your peace', Franciscan Communications Center, Los Angeles. 
van die groep. Die een in die groep kan nie vir die ander in dieselfde groep sê dat ek jou nie nodig het nie. Die koestering van jou eie liggaam is as ' $t$ ware die beskerming van die appel van jou eie oog (ThomasEvang 25:1-2). Selfsug is om 'n 'bose oog' te hê (vgl. Fiensy 2007:12; Longenecker [1998] 2001:152). Die grens van jou liggaam is metafories die grens van jou groep. In die antieke Mediterreense wêreld is die grens veranderlik en verskuif dit vanaf die uitgebreide familie tot die ethnos (kultuurgroep). Die grens verskuif in der waarheid waar jy tuiskom en dit veronderstel 'n beweging in 'ringe': Judea, Galilea, Samaria, Sirië, KleinAsië, tot by Rome. Hierdie telkens verskuiwende grens word geografies, biologies en etnies gedefinieer. Fenotipiese aspekte, soos velkleur en gesigs- en oogtipiese kenmerke, is nie dié onderskeidende sake wat grense daarstel nie. In die meertalige Semities-Hellenisties en Hellenisties-Romeinse wêreld het selfs nie taal grense vasgestel nie (vgl. Duling [2003] 2008:799-818). Religie het wel 'n rol gespeel, maar nie as 'n entiteit op sigself nie. Religie was ineengeweef met die 'natuurlike' geografiese, biologiese en etniese groepskwalifikasie. God is die God van Israel, soos die Shema-gebed dit duidelik in Deuteronomium 6:4-5 uitdruk, en deur Jesus se 'naasteliefde'-gebod in Markus 12:28-34 herhaal word (vgl. Meier 2009:490-495). Wanneer die 'kerk' (ekklessia) die term word (by o.a. Paulus, Matteus en Lukas) vir die 'nuwe' gemeenskap wat Christus-volgelinge daarstel, verander die 'grens', sodat ons as 't ware van 'n 'oorgrens' groep kan praat. Waar die liefde vir die 'naaste' (in Grieks plèsion; in Hebreeus réa) in Levitikus 19:18b doelbewus verder in 19:34 gekwalifiseer word om ook die 'bywonervreemdeling' (ger) in te sluit (kyk Gerstenberger 2014:28, n. 2; Meier 2009:494), verval hierdie kwalifikasies geheel-enal in Christelike etiek wat op Jesus se 'naasteliefde'-gebod gebaseer is (Malina 2008). ${ }^{4}$

\section{Rudolf Bultmann se opstel oor Christelike 'naasteliefde'}

Dit wil lyk asof hierdie opstel oor 'Christelike naasteliefde' van 1930 geskryf is vir Christene wat steeds 'gekwalifiseerd' oor die begrip 'naaste' dink en etiek nie as 'n 'oorgrens'ervaring verstaan nie.

Etiek verwys vir Bultmann na optrede wat gemotiveer word met óf die imperatief dat jy dit of dat móét doen óf doodgewoon omdat jy in 'n verhouding met iemand anders is, wat die 'Ich und Du'-relasie genoem kan word (Bultmann [1930] 1958:229). Wat eersgenoemde betref, kan die fokus gelê word op óf die resultaat van jou pligpleging óf op die handeling self. ${ }^{5}$ Wanneer mense, bewustelik of onbewustelik, hulle oog op eerder die gevolge van hulle daad het as op die

4.In sum, to understand neighbour one might imagine three concentric social rings the centre ring includes people obliged by mutual generalized reciprocity, one's local, everyday neighbours. The next ring includes people obliged by balanced obligations, tit for tat, here referring to the house of Israel. A third ring, left outbounded on the outside, consisted of people to whom one is not bound at all' (Malina 2008).

5.Vergelyk Bultmann (1958:229, n. 1 en n. 2) se aansluiting by Emil Brunner se werk Der Mittler: Zur Aufgabe der Christologie. Beide Emil Brunner en Rudolf Bultmann, wat die 'Ich-Du'-relasie betref, sluit in hulle gebruik van terme aan by Ferdiand Ebner (1882-1931) en Martin Buber (1878-1965) (kyk Casper 2002; vgl. Smith 2006:22-23) daad self, blyk dit dat een of ander ideaal belangrik is. Met ander woorde, as jou optrede gelei het tot die verwesenliking van dit wat jy as 'n ideale toestand sou reken, dan sal die handeling as 'goed' getipeer kan word. Die doel regverdig dus die daad (Bultmann 1958:229). Die gevolg is dat die verskil tussen wat die meer ideale en die minder ideale toestand sou wees, in so 'n etiek nie 'n belangrike oorweging is nie. Die verwesenliking van die doelwit neem egter nie weg dat, omdat wat ek doen, 'n resultaat tot gevolg het, die afstand tussen waar ek my bevind (Sein) en waar ek wil wees (Sollen), wel in 'n mindere of meerdere mate deur my handeling oorbrug word (Bultmann 1958:229-230).

Die bereiking van so 'n 'doel' hoef nie die enigste motivering te wees van my strewe om 'n imperatief te gehoorsaam nie. Dit kan ook 'n outoriteit wees wat op my aanspraak maak en hierdie eksterne gesagsaanspraak kan die rede wees waarom ek iets gedoen het. In so 'n geval is daar geen 'waarom'-vraag (Warum?) ter sprake nie en ook nie die vraag 'om watter rede' [Wozu?] nie (Bultmann 1958:230). Uiteraard het my optrede gevolge. Wat egter nie meer relevant is nie, is die kwessie of dit 'n goeie of slegte gevolg is.

Daar is dus ' $n$ verskil tussen die gebruik van die uitdrukking 'behoort' en die uitdrukking 'moet'. Die 'etiek van behoort' is nie gebaseer op wat 'móét' nie. Dit gaan eerder om 'n gehoorsaamheid aan 'n opdrag. Die etiek wat ter sprake is, is dus dié van gehoorsaamheid as sodanig en nie die strewe om 'n ideaal te verwesenlik om die afstand tussen waar ek my bevind [Sein] en waar ek graag sal wil wees (Sollen) te oorbrug nie (Bultmann 1958:230). So gesien, gaan dit nie om die skep van beter omstandighede of om die daarstelling van 'n beter samelewing nie. Die enigste móét wat ter sprake is, is of ek aan die eksterne gesag gehoor gegee het of nie. Die resultaat waarvan hier gepraat word, het met ander woorde nie transformasie van 'n bepaalde situasie in die oog nie, maar bloot die gegewe dat iets in die werklikheid gebeur het of gedoen is. ${ }^{6}$ Die eksterne outoriteit bepaal die hier-en-nou [Jetzt] van die mens en nie sekere ideale (of die verwerkliking van 'n ideologie) nie (Bultmann 1958:230).

\section{'Ich und Du'-relasie}

Omdat Bultmann geen onderskeid tussen 'sakrale' en 'profane' etiek maak nie, is die aard van die etiek by 'n gelowige en ongelowige vir hom dieselfde. Ook wat die lewe van 'n Christen betref, het die etiese imperatief dus twee kante (Bultmann 1958:230): betekenisvolle hier-en-nou (Jetzt) behoort (1) nie deur een of ander ideaal beheers te word nie, maar (2) eerder deur 'n eksterne 'aanspraak'. Tog is daar hier 'n paradoks aanwesig: ons as Christene behoort ons daaraan te bly herinner dat ons etiek veelmeer deur 'n 'Ich und Du'relasie gekenmerk word, dit wil sê, deur my verhouding met iemand anders, eerder as deur 'n eksterne abstrakte gesagsaanspraak of bewustelike of versweë ideologie.

6.Dit is in sulke kontekste dat mense, soldate of offisiere, of die massa, bloot onnadenkend populistiese of charismatiese leiersfigure, gedryf deur 'n fanatieke ideologie (o.a. Nazisme of patriotiese nasionalisme, facisme, ens.), as ' $t$ ware ideologie (o.a. Nazisme of patriotiese nasionalisme, facisme, ens.), as 't ware
blindelings volg en selfs tot uiterste dade van kwaad en skade teenoor ander kan oorgaan. 
Dit is belangrik om te onthou dat geen menslike handeling in ' $n$ vakuum plaasvind nie, maar dat dit konkreet in die wêreld geskied. Wat ons ook al doen, gaan direk of indirek mense rondom ons raak (Bultmann 1958:230). 'n Handeling is 'eties' wanneer dit tussenmenslike verhoudings (Miteinandersein) beïnvloed. Dit geld daar waar ons met ons optrede uit eie wil idealiter die samelewing wil verbeter en ook daar waar 'n eksterne aanspraak deur die ander op my gemaak word omdat die ander (das $D u$ ) vir my belangrik is. My optrede raak iemand direk wanneer die ander in my onmiddellike gesigsveld is en indirek wanneer die ander vir my gesigloos is.

Daar is ook ander soort indirekte optredes. Dit is handelinge op terreine soos die tegniek, die kuns en die wetenskap. Hierdie optredes kan breedweg 'kultuurhandelinge' genoem word (Bultmann 1958:231). Hoewel sulke handelinge indirek is omdat spesifieke mense nie in die gesigsveld is nie, raak dit wel mense altyd op een of ander manier.

In direkte verhouding met die ander, in die eerste plek omdat ek in verbintenis (Verbundenheit) met die ander is, voltrek etiek wanneer ek, teen die aanspraak van watter gesag ook al op my hier-en-nou, gehoorsaam is aan die móét-daad ter wille van die ander met wie ek in verhouding is. Dit wil sê, afgesien van enige aanspraak op my, gaan ek eties korrek optree. Dit is in hierdie verband waar die Christelike opvatting oor die 'naaste' ter sprake kom (Bultmann 1958:231).7 Iemand is nie my 'naaste' as ek eers vir die ander moet opsoek nie. My 'naaste' is dié persoon of persone wat eenvoudig net daar is waar ek is (Bultmann 1958:231). ${ }^{8}$

Geen handeling vind in 'n leë ruimte plaas nie (Bultmann 1958:231). ${ }^{9}$ My 'naaste' is egter ook nie slegs diegene met wie ek in bepaalde bestaande verhouding of verwantskap is asof my naaste 'n objek is vir wie ek as gevolg van die betrokke relasie (bv. ouer-kind, of landgenoot, of volksgenoot) móét omgee en versorg nie. Met ander woorde, ek vra my nie eers af wie die ander is en hoe die ander aan my verbind is, voordat die persoon as my naaste geag word nie (Bultmann 1958:231). Dit is eerder só: my 'onvoorwaardelike wees' is 'n 'wees-met-ander' (Sein von vorherein (ist) ein sein mit Anderen) (Bultmann 1958:231).

Die vraag 'wie is my naaste?' en die vraag 'wat sal ek vir jou kan doen?' is verleidelik omdat dit daartoe kan lei dat ek my liefde op self-liefde en selfbelang begrond. ${ }^{10}$ Sulke vrae impliseer dat ék in staat is om mý eie lewe op grond

7.Dit is nie "Christelik' (contra Brunner 1927:561) omdat ' $n$ individu - en nie ' $n$ gemeenskap nie - ter sake is nie. Christelike etiek raak individue én gemeenskappe (Bultmann 1958:231).

8.Vergelyk Martin Heidegger (1927:52-54) se begrip 'Vorhandenen' (Bultmann 1958:231, n. 2)

9.Ebeling (1969:69), in navolging van Bultmann, beklemtoon dat ook om te glo nie in 'n leë ruimte gebeur nie, dit wil sê in 'n 'selbsterrichtete Getto', 'n 'falsche Ort' nie. Dit is alleen binne in die werklikheid van hierdie wêreld dat geloof betekenis het en die gelowige ook bring om solidêr krities met wêreldse dinge om te gaan (vgl. Beutel 2012:261)

10.Volgens Lukas 10:25 word die vraag deur'n wetgeleerde (nomikos) aan Jesus gevra met die doel om die 'ewige lewe te erf', en in Lukas10:29 vra hy vir Jesus: 'en wie is my naaste?' (kai tis estin mou plēsion). van mý eie vermoë te voer. Dan verbeel ek my dat ék kan bestaan, ${ }^{11}$ sonder dat jý in die wêreld vir my daar hoef te wees. Die ' $I c h$ ' is egter nie sonder die ' $D u^{\prime}$ moontlik nie! Indien jy wel só dink, is die 'jy' - in Heidegger (1927:52-54) se terme - bloot voorhande as 'n verskynsel in die wêreld wat ek as objek kan waarneem, mee kan handel en manipuleer ('ein vorhandenes Weltphänomen') (Bultmann 1958:231, n. 2). Die 'jy' is dan slegs vir my 'n gegewe, onaktiewe objek, bestaande uit 'Welt-Stoffes' (Bultmann 1958:231), so asof die 'jy' eers nog met 'my' in relasie móét tree. So 'n siening berus op 'n misverstand ten opsigte van die menslike kondisie waar slegs sekere mense aan die kwalifikasie as 'naaste' voldoen - so asof mense hulle in 'n neutrale toestand bevind (Bultmann 1958:232).

\section{Die invloed van die Griekse filosofiese etiek}

In die Griekse filosofiese etiek word etiese handelinge meesal na analogie van die 'tegniek' (technē) verstaan. Deur middel van kunstige handewerk word objekte gevorm en herstel. Die mens is so 'n kunswerk en die onderskeid 'Ich' en ' $D u^{\prime}$ ' is in so 'n denkraamwerk nie bewustelik ter sake nie (Bultmann 1958:232). Met die kunswerk word 'n doel (telos) bereik. Die 'doel' is 'n ideale eindtoestand. In die voor-Stoa periode kon die mens as individu of as deel van die polis - of as polis in die sin van mede-individue (kosmopoliteia) - wees. In die konteks van die Stoa val die fokus nie op óf die individu óf die mede-individue nie, maar universeel op die ganse mensheid (Bultmann 1958:232). In die voorStoa-etiek is die doel die verwesenliking van die ideale polis of kosmopoliteia. In die Stoa word die polis-ideologie met die begrip 'koninkryk van God' (basileia) ${ }^{12}$ as die 'goddelike huishouding' (divine economy) vervang. ${ }^{13}$ Uit 'n individuele perspektief gesien, is die doel die 'mooie en die goeie' (kalokagathia) ${ }^{14}$ ofte wel geregtigheid (dikaiosunē) en die ideale toestand word dan as die goed georganiseerde kosmos (in Aristoteliese voor-Stoa sin) beskryf. Die 'kosmos' is die geordende, gestruktureerde harmonieuse vorm wat die eindproduk van die tegniek vorm. Die 'Self' is slegs die

11.Die mens se daar-wees is dus nie anders as die daar-wees van die natuur op sigself nie. Elke mens het ' $n$ geskiedenis en ook die geskape natuur het ' $n$ geskiedenis (evolusie - A.G.v.A.). Die bestaan van die mens (geschichtliches Sein) (Bultmann 1958:231) is dieselfde as die natuur wat bestaan.

12.Vergelyk Van Aarde (2014b).

13. Brent Shaw (1985:29-30) beskryf die 'universele etiek' van Epictetus (Discourses 1.23.1), as konstitutief deel van die kosmos - volgens Aristoteles, as deel van die polis - soos volg: 'To Epictetus the essence of the whole new order in which man is to be situated in short, the very essence of Stoicism itself, was in which man is to be situated in short, the very essence of Stoicism itself, was encapsulated in his summation: 'The divine economy, and how and what sort
of rule a reasoning being as in it'. Epictetus further specifies the superimposed of rule a reasoning being as in it'. Epictetus further specifies the superimposed layers of social roles that constitute the hierarchy of the Divine Economy. In
one of his most explicit statements (Discourses 1.10; 2.10), he claims that every man has a "cosmic" vocation, namely that of being a human [epangelion anthropou] but that this grande profession is composed of a subordinate subset of vocations (an overarching order of things in which "all men are brothers"). One is:

1. a human being [to proton anthropos]

2 a citizen of the world [polites tou kosmou]

3. an active, not just a passive or servile, part of the world

4. one who can comprehend the divine economy [dioikesis theia]

5. one who has the vocation of citizen of a state [epangelion politou]

6. one who shares given genetic roles (e.g. son, brother) and given social roles (e.g. town councillor, soldier).'

14.Vergelyk ' $n$ resente studie oor die begrip 'kalokagathia' ('mooi en goed') (Weaver 2008). 
boumeester wat aan die 'Self' as stof vorm gee (Bultmann 1958:232). ${ }^{15}$

In die Griekse denke kom intermenslike verhoudinge daar tereg, vanuit die perspektief van die 'móét-etiek', waar dit die paideia raak, dit wil sê die kultuur en die opvoeding. Binne hierdie konteks is die ander nie my naaste nie, maar die objek van my strewe (ergon) om 'n ideaal te verwesenlik. In die uitvoering (ergazesthai) is my 'Self' doof vir enige aanspraak, behalwe vir dié van die verwerkliking van ideologie. Mense as die ander is hoegenaamd nie direk of selfs indirek in onderskeidelik my direkte gesigsveld of indirek by implikasie belangrik of eers neutraal ter sake nie. Ek handel sonder dat ek aan individue of gemeenskappe dink. So gesien, sal ek myself dus slegs verbind aan die strewe om dié idée se einddoel (telos) te bereik. Tussen my (Ich) en jou $(D u)$ is daar egter geen fundamentele verskil nie. Ek bestaan ter wille van die verwerkliking van die ideaal en jy bestaan ter wille van dieselfde strewe (Bultmann 1958:233). Jy maak geen aanspraak op my nie en ek maak geen aanspraak op jou nie. Daar is geen etiese relasie tussen ons nie. Ons altwee word deur dieselfde ideaal se einddoel gedetermineer. Ek is nie aan jou óf geregtigheid óf onreg verskuldig nie en jy ook nie aan my nie. Die 'goeie' en die 'bose' word deel van die uitvoering van die strewe van die verwesenliking van die ideaal. Die etiese gevolge van my handeling is toevallig. Die mens op sigself verdwyn agter die najaag van 'n ideologie. Intermenslike etiek is indifferent. Wat oorheers, is die ideologie om 'n geordende kosmos in ooreenstemming met my/ons ideologie daar te stel.

Hierdie Griekse denke het steeds in die Westerse wêreld ${ }^{16}$ 'n nawerking (Bultmann 1958:233). In die periode van die Aufklärung (bv. die Hegeliaanse ideealteorie) en in die etiek van die (nasionaal-, of materialisties-kommunisties, of Christelik-nasionale) sosialisme as ideologie, het die individualistiese 'personaliteitsideaal' 'n doel op sigself geword (Bultmann 1958:233). Dit neem nie weg dat die etiese appèl ten opsigte van die individu insgelyks op dié spesifieke vraag berus, naamlik 'wat móét ek doen?' nie.

Die probleem is egter dat etiek in hierdie konteks so deur die esteties-tegniese begripsmateriaal deursuur is dat die voorAufkläring (Stoïsynse) voorstelling van 'Miteinandersein' verlore gegaan het. Dit geld ook sistematies-etiese modelle waar begrippe soos 'geregtigheid', 'outentisiteit' (= 'waaragtigheid'), 'getrouheid' en 'reinheid' nie primer op 'n 'ideale toestand' betrekking het nie (Bultmann 1958:233). Hierdie 'deugde' dui eerder op bepaalde optredes (Vollzug der Handlung) as dryfvere in die verwesenliking van 'n ideologie. Dit beteken

15.Volgens Bultmann (1958:232) het die begrip "deug' (aretē) in so " $n$ verwysingsraamwerk funksioneel geword. Deugdelikheid word as arbeid (ergazesthai/ergon) gesien. Dit is opvallend dat die Ou Testament nie 'n vertaalekwivalent vir aretē het nie en dat met Hellenisme die gebruik van die begrip 'deug' in Israelitiese denke opgeneem is. Dit is 'n begrip wat nie in die Jesusbegrip deug in Israelitiese denke opgeneem is. Dit is ' $n$ begrip wat nie in die Jesustradisie voorkom nie. In die Nuwe Testament is dit volgens Bultmann (1958:232) 'n randsaak (Fil 4:8; 2 Pet 1:5; vgl. 1 Pet 2;9 en 2 '
uitdrukking 'goddelike deugde' (aretai / aretē).

16. Hier word bedoel die tyd kontemporêr aan die periode toe Bultmann sy opstel oor naasteliefde, eers in Frans in 1930 gepubliseer het, toe die Duitse vertaling daarvan in 1933, en daarna die opname van sy opstel in Glauben und Verstehen in 1958 dat die ideologie self nie geregtigheid (onder andere) as bousteen het nie. Om te doen wat reg is of om onreg te pleeg is nie die betrokke ideologie as sodanig se doelwitte nie; dit is werkinge in die proses om 'n ideologie na te jaag. Wat erger is, is dat in dié proses die ' $I c h$ ' probeer om deur middel van sulke optredes sigself van die 'Du' te bevry (Bultmann 1958:233). In die huidige Westerse konteks (Bultmann se 20ste-eeuse) gaan dit dus nie meer daarom om begrippe soos 'geregtigheid' en 'waaragtigheid' as persoonlike kwaliteite toe te eien nie. Dit gaan eerder om téén - ten koste van - die ander se geregtigheid en getrouheid te lewe. Die ideologie (bv. nasionaal-sosialisme, Christelik-nasionalisme, kommunisme) oorheers, bewustelik of onbewustelik. In ' $n$ 'Ich-Du'-relasie is die ander egter nie vir my slegs 'stof' waarop ek kan trap, waaroor ek überhaupt kan loop nie. 'n 'Ich-Du'-relasie veronderstel 'n etiese verhouding waar kwaliteite soos geregtigheid en reinheid 'n doelbewuste gerigtheid op die ander het.

Dit is dus duidelik dat begrippe soos 'geregtigheid', 'outentisiteit' en 'reinheid' slegs 'n formele struktuur vir etiek daarstel en nie werklik 'n konkrete sleutel voorsien om 'n antwoord te vind op die vraag 'wat móét ek doen?' nie (Bultmann 1958:233). Die handelinge wat hierdie begrippe impliseer, bied nie 'n beskrywing van 'n ideale toestand nie. Die 'Ich-Du'-verhouding het verlore gegaan en het hoogstens in 'n sterk abstrakte sin in die Kantiaanse 'kategoriese imperatief' (ek doen die goeie omdat ek móét en nie omdat ek iets daardeur wil bereik nie) bly voortbestaan. Volgens Bultmann is filosofiese etiek beperk tot hierdie soort abstrakte denke (Bultmann 1958:234).

Die formele struktuur vir Christelike etiek behoort eerder in die grondstelling van die konkrete Dasein begrond te word, indien dit die moontlikheid van 'n 'Miteinander' wil handhaaf. 'n Etiese situasie behoort daarom 'eksistensiaal' (existential) en nie 'eksistensieel' (existentiell) geïnterpreteer te word nie (Bultmann 1958:234). Indien etiek bloot op die eksistensiële vlak bly, bly 'n daad abstrak in die lug (op die vlak van die Sein) hang. Dit is op die eksistensiale vlak dat die daad (op die vlak van die Dasein) konkreet word in 'n verhouding tussen jou en my ('Ich-Du') (Bultmann 1958:234).

Die probleem het dus gekom toe die mens slegs as 'stof' ('n objek) gereken is en etiek bedink is vanuit die perspektief dat mens-wees nie 'n eties-gesitueerde 'Miteinandersein' is nie.

\section{Die liefdesgebod}

Gesien vanuit hierdie perspektief, kan die Christelike gebod van naasteliefde inderdaad die antwoord op die vraag 'wat móét ek doen?' bied. Volgens Bultmann sal die antwoord 'n dialektiese 'ja en nee' wees (Bultmann 1958:235).

Die antwoord is 'nee' as liefde nie die resultaat van 'n handeling is wat op 'n doel of op die ideaal dui nie. Dit gaan nie om die handeling op sigself nie, maar oor dié een op wie die handeling gerig is. Die antwoord is 'ja' as die persoon aan wie ek liefde betoon, belangriker is as die formaliteit 
van onder andere geregtigheid. Op die eksistensiale vlak (Dasein) ontdek ék vir jóú in die doen van wat reg en waar is. Liefde is nie ' $n$ teoretiese etiese handeling nie. Liefde is nie 'n 'Materialprinzip' nie (Bultmann 1958:235). Liefde is nie die daad om 'n ideologie te bestendig of die uitvoer van 'n doelwit nie. Liefde is nie die blindelingse gehoorsaamheid van 'n reglement van sogenaamde korrekte optredes nie. Om lief te hê is nie ' $n$ middel tot ' $n$ doel nie. Dit is nie die begronding van 'n handeling wat voortspruit uit die kennis (wetenskap) wat ek opgedoen het om aan jou goed te doen, soos 'n psigiater of sielkundige wat tot die voordeel van' $n$ mens met die bepaalde mens in interaksie is nie. Die eis om liefde te betoon, soos dit in Jesus se Bergrede voorkom of in Paulus se 1 Korintiërs 13 (Bultmann 1958:235), het nie met die vraag wat ek móét doen ('ein Was des Handelenes') (Bultmann 1958:235) te doen nie en ook nie met die realisering van deugde nie. Liefde is baie meer as dit. In streng konkrete sin is liefde die uiting van 'n verreikende insig in wat dit is dat ék in 'n verhouding met jóú staan. Liefde is nie 'n teoretiese saak nie, maar praktiese. Dit wat ek doen, het in liefde gerealiseer. Die 'ek-jou-relasie' behoort dus nie in algemene terme soos geregtigheid verstaan te word nie (Bultmann 1958:235). Dit word geleef in 'n konkrete spesifieke situasie waar jy nie jou 'naaste' gaan soek en vind nie. Jy gaan jou naaste daar vind waar jy jou bevind en wat jy gaan ontdek, is dit wat jy móét doen (Bultmann 1958:235).

Daar kan wel van 'n formele karakter van liefde gepraat word, naamlik in die sin dat ek oor 'n baie spesifieke verbintenis tussen 'Ich' en 'Du' en 'n daadwerklike interaksie (Tun) kan verstaan en praat (Bultmann 1958:235). Dit veronderstel dat ek myself verstaan op grond van my verbintenis met die naaste. My verklaring van die begrip 'naaste' stel die teorie van etiek aan die orde (Bultmann 1958:236). Liefde is egter nie ' $n$ teoretiese saak nie. Liefde het nie eers gerealiseer toe ek die begrip 'naaste' geanaliseer het nie. Daar waar $e k$ die naaste as my naaste sien, daar is 'liefde' (Bultmann 1958:236). Alle mense is my naaste (Bultmann 1958:236). Ek kies nie wie ek as my naaste wil sien nie. Die betoning van liefde is ook nie iets wat eers met die Christelike kerk gekom het nie. Die novum vir Christene is geleë in die woorde 'jy moet jou naaste liefhê soos jy jouself liefhet'.

Om saam te vat: naasteliefde word verkeerd verstaan as dit gegrond word in die etiese imperatief wat deur ' $n$ bepaalde ideaal beheers word. Dit vind jy wel in die Griekse (en Stoïsynse) etiek. Seneca (De otio 1.4) sê byvoorbeeld (vgl. ook Plato, Crito 49b-49e): 'Laat ons nie moeg word vir die algemene welsyn nie, naamlik om individue, ook die vyand, te help' (Bultmann 1958:236, n. 1). In diatribe-styl reageer die denkbeeldige gespreksopponent deur te sê dat om met tye toornig te wees tog aanvaarbaar kan wees. 'Nee', antwoord Seneca, 'weldade is eerbaar, dit wil sê om goed met goed te vergeld, en net so, nie onreg met onreg nie'. Wat ons hier aantref, is die eis om liefde wat in humanitêre oorwegings gegrond is; met ander woorde die menslike ideaal wat uit ervaring weet dat wedersydse onreg nie harmonie daarstel nie. Volgens Seneca (Epistula 95.33) is homo, res sacra homini, in Engels vertaal as 'Man, an object of reverence in the eyes of man'. Dit wil sê, die mens is as mens waardevol, heilig en goddelik. Hier word die grond vir menseliefde gevind en die kroon hierop is die liefde vir die vyand (Bultmann 1958:237). Omgekeerd, waar liefde op grond van hierdie ideaal aan my betoon word, word my mens-wees gebou.

In Christelike konteks gaan dit egter nie om menseliefde in die algemeen nie. Liefde is nie 'n deug nie. En die selfvervulling van my mens-wees is nie van menseliefde afhanklik nie. Liefde is nie 'n eienskap wat 'n mens besit nie, soos byvoorbeeld selfbeheersing en geleerdheid nie. Dit is natuurlikerwys ook nie 'n gevoel, 'n affek, wat'n individu kan ervaar nie (Bultmann 1958:237). Dit is 'n onvoorwaardelike wyse ('von vornherein eine Weise') van wees-in-verhoudingmet-ander (Bultmann 1958:237). Søren Kierkegaard ([1890] 1924:229-231) het gesê: 'Jy kan nie liefde as eienskap of besitting vir jouself toeëien wat jy dan weer vir ander kan gee nie'. Liefde is überhaupt geen eienskap, geen kenmerk van 'n mens nie ('Was am Menschen'), maar 'n tussenpersoonlike aangeleentheid ('Wie seines Miteinanderseins') (Bultmann 1958:237). Die Christelike liefde gee; dit begeer (epithumia) nie (Bultmann 1958:237). Dit is nie soos die antieke Erōs, kind van Penia, wat in die mistiek trapsgewys van geringe na hoëre wil beweeg om dit in besit te neem wat nog nie gekry is nie (Bultmann 1958:237). Jy het nie lief om oordeel te vermy nie.

Die opdrag tot Christelike liefde word eers in die liefde ontdek. Dit keer die natuurlike mens se lewensrigting om (Bultmann 1958:238). Natuurlikerwys wil die mens die ék van die jý skei om die ék teenoor die jý te handhaaf. Die liefde vra dat die ék oorwin sal word om die self in diens van die ander binne 'n konkrete lewensituasie te stel. Die uitdrukking 'jy moet jou naaste liefhê soos jouself' vra nie 'n algemeen menslike liefde wat gebou word op 'n abstrakte idee van wat 'menswaardig' is nie ('die begründet wäre durch einen abstrakten oder idealen Wert des Menschen') (Bultmann 1958:238). Op die grondvlak is my liefde vir konkrete mense met wie ek in kontak kom, op niks anders begrond nie as dat hulle mý naaste is nie. Die antwoord op die vraag 'wie my naaste is', verstaan ek net werklik deur konkreet lief te hê (Bultmann 1958:238).

Die vraag 'wat móét ek doen?' behoort nie gestel te word in die vorm van 'wat moet ek as iemand wat liefhet, doen' nie? Ook nie in die vorm 'wat moet ek doen om lief te hê' nie. Die antwoord op hierdie soort vraag (wat eintlik nie gevra behoort te word nie) is: 'soos jouself'. Of anders gestel: 'wat jy wil dat ander aan jou doen, dit doen jy aan hulle' (Bultmann 1958:238). Laasgenoemde is 'n eenvoudige reël om toe te pas. Dit betaam daarom om die een wat vra 'wat moet/behoort ek (te) doen?', te wys op die natuurlike liefde van mense vir die self. Wie hulleself liefhet, weet hoe hulle wil hê dat die ander hulle sal liefhê; wie die ander liefhet, weet ook wat hulle aan die ander behoort te doen.

Die liefdesgebod beskryf dus nie wat liefde is nie, maar wys die een af wat daarna vra, so asof die liefdesgebod nie genoegsaam sê wat gedoen behoort te word nie. Hoewel die 
liefdesgebod nie sê wat liefde is nie, maak dit diegene wat die vraag stel, 'wat moet/behoort ek (te) doen?', daarvan bewus dat hulle dit vra juis omdat hulle nie genoegsaam liefhet nie (Bultmann 1958:238). Volgens Martin Luther (EA, in Bultmann 1958:238, n. 1) is so 'n vraag nie net dom ('törich') nie, maar liefdeloos.

Die liefde is dus nie net 'n etiese beginsel waaruit riglyne vir die ideale manier van lewe of vir die ideale toestand van menswees afgelei kan word, soos wat met 'n humanistiese liefdesbeginsel die geval is nie. Die liefdesgebod dring mense daartoe om in konkrete lewensituasies hulle naaste raak te sien en te weet wat hulle te doen staan (Bultmann 1958:239). ${ }^{17}$ 'n Christelike etiek in die sin van 'n bepaalde teorie of sisteem oor wat Christene behoort te doen en nie te doen nie, bestaan dus nie. Om die naaste lief te hê, het nie te doen met ' $n$ tydlose idee oor menswees nie. Dit is gerig op menswees in die tyd en in die geskiedenis - 'n baie spesifieke mens wie se konkrete bestaan op die spel is; ' $n$ mens wat oor moontlikhede beskik en wat voortdurend te staan kom voor die besluit om lief te hê of nie.

Die Christelike liefde is ook verborge. Dit is nie sondermeer sigbaar in 'n stuk arbeid (ergon) of in een of ander besitting (ktēma) nie (Bultmann 1958:239, n. 2). Diegene wat liefde betoon, kan nie self hulle spesifieke optrede as 'liefde' beskryf nie. Wie hulle self is en wat hulle doen, is twee entiteite wat as ' $t$ ware naas mekaar staan. Mense kan die onsekerheid van hulle menslike bestaan nie probeer oorkom, deur een of ander daad (ergon) nie. Mense arriveer nooit nie. Dit beteken dat die liefdesgebod tegelyk onvervuld bly en dat die oproep tot liefde nooit ophou nie (Bultmann 1958:239-240). As 'n mens in die versoeking kom om jou eie weldaad as liefde te beskryf, is die versoeking inherent dat jy jou doen van liefde as afgehandel kan beskou. Liefde het nie die tyd om sigself te ondersoek nie (Bultmann 1958:240).

Jy behoort daarom 'n kritiese 'afstand' tussen wie jy self is en wat jy doen, te handhaaf, sodat jy nie te maklik aan die versoeking toegee om te dink dat, wanneer jy liefde bewys het, jy kláár of genoegsaam liefgehad het nie. Mense bly dit steeds en aanhoudend aan mekaar verskuldig om mekaar lief te hê (Rom 13:8). Isolasie is teen die aard van die liefde. As die liefde 'n objek (van refleksie) word, kan dit die kwaliteit van 'n opdrag wat nooit ophou nie, verloor, en word liefde 'n ding net soos ander dinge wat deel van die verganklike en die verbygaande is.

Die opdrag tot agape is die grondslag van die menslike Dasein. Deur doen, deur lief te hê, verwesenlik mense hulle menswees (Sein). Die 'doen van liefde' gaan nie oor 'n abstrakte idee of oor 'n gesiglose menswees nie, maar oor werklike mense wat in die uitoefening van hulle keuses hulle moontlikhede verwesenlik. Die historiese werklikheid behoort nie verstaan te word as wat gedoen is nie (d.w.s. as afgehandelse sake van die verlede nie), maar eerder as wat in proses is wat gedoen

17. Bultmann (1930:239, n. 1) haal Augustinus se woorde aan: ama, et fac quod vis ['wees lief, en doen dan wat jy wil'], 'Tractatus VII.8' (Homily 7 on the First Epistle ['wees lief, en doen dan wat jy wil'], 'Tractatus VII.8' (Homily 7 on the First Epistle
of John [1 Joh 4:4:4-12], in Philip Schaff (ed.), [1888] 2009, From Nicene and postNicene fathers; vgl. ook Davies 1991). word. Die historiese werklikheid kan nie naas die handeling van liefhê gestel word en as ergon verstaan word nie, maar eerder as hodos (Bultmann 1958:240). 'n Uitdrukking soos die 'hodos van die agape' (die 'weg van die liefde') artikuleer menswees as 'n moontlike bestaanswyse van wees deur te doen. Om mens te wees is geen passiwiteit nie, maar ' $n$ wees op weg na die toekoms; die handeling van om lief te hê en weer lief te hê en weer lief te hê. ${ }^{18}$

Kan 'n mens dus sê wat die liefde is? Hoegenaamd nie (Bultmann 1958:240). Wie die mens sien as geïsoleerde subjek en as abstrakte mens, sal liefde nie kan verstaan nie omdat liefde plaasvind in saamwees en net in verbondenheid verstaan kan word. Liefde is die kuns van 'saam-met-die ander' ('eine Art des Miteinanderseins') te wees (Bultmann 1958:240). Die keuse om lief te hê, is in werklikheid nie 'n keuse om lief te hê nie, maar is reeds om lief te hê. Ons kan daarom ook nie sê dat 'n persoon wat liefhet, nie weet wat dit is om lief te hê nie, omdat die persoon reeds liefhet (Bultmann 1958:240). Diegene wat vra wat dit is om lief te hê, wou met woorde geantwoord word deur hulle waan te bevestig dat hulle wel weet en dat hulle reeds liefhet as 'n daad wat in die verlede gedoen is, en nou in die hier-en-nou in der waarheid liefdeloos is - daarom weet sulke mense nie wat liefde is nie (Bultmann 1958:240). Benewens 'n antwoord met woorde op sulke mense se vraag, sou hulle ook met die daad geantwoord kon word - 'n daad van liefde jeens mense wat self liefdeloos is (Bultmann 1958:240).

Liefde as moontlikheid vir die menslike bestaan (Liebe als Existenzmöglichkeit) kan net begryp word as dit'n werklikheid word in die saamwees van mense in die ' $I c h^{\prime}-' D u^{\prime}$-verhouding (Bultmann 1958:240-241). Dan sal dit herken word as iets wat reeds daar is. Op die vraag na wat die liefde is, kan mense eenvoudig terugverwys word na die werklikheid van hulle eie bestaan (Bultmann 1958:241, n. 1). Liefde is egter nie as 'n saak ('n iets of 'n ding) in die menslike werklikheid herkenbaar nie. Die sin van die liefde of die werklikheid daarvan kan nie van buite af raakgesien word nie. Mense kan nie liefde by hulleself en in hulle eie gedrag raaksien of aantoon nie.

Mense kan ook nie hulle liefde vir die ander aan die ander verduidelik nie (Bultmann 1958:241). Die ander kan liefde net herken wanneer hulle binne die saamwees geliefd is ('wenn er sich in seinem Mit-andern-sein als Geliebten zu verstehen vermag') (Bultmann 1958:241). Vir die ervaring van liefde is daar nie aanduibare kriteria nie. Net diegene wat glo dat die liefde bestaan, kan dit herken en ontvang (Bultmann 1958:241). ${ }^{19}$

\section{Geloof in God se liefde maak geloof in liefde én lewe moontlik}

Die vraag is waar hierdie geloof vandaan kom. As liefde die natuurlike lewensrigting van mense omkeer, sal dit moeilik

18. Die uitdrukking kopos tês agapēs [ die “inspanning van die liefde'] in 1 Tessalonisense $1: 3$ behoort daarom in die lig van 1 Korintiërs $13: 1-3$ verstaan te word. Bultmann $(1958: 240, n .1)$ verwys in hierdie verband instemmend na Kierkegaard (1924: 183-214).

19.'Die Liebe is nur dem Glauben an sie sichtbar' (beklemtoning deur Bultmann 1958:241). 
wees om te glo dat die mense met wie 'n mens in verhouding is, jou werklik liefhet. Hulle is tog natuurlike mense net soos ek. Watter mens kan hierdie ommekeer van lewensrigting bewerkstellig? 'n Mens staan nie buite jouself sodat jy jouself kan omkeer nie. Die mens moet eintlik omgekeer word. Weer eens: om te besluit om lief te hê is nie 'n besluit om lief te hê nie, want die liefde moes al vantevore daar gewees het.

Of is dit as antwoord op die vraag waar hierdie geloof vandaan kom, voldoende om met 'n teenvraag te vra of liefde in verskillende vorme in menslike saamwees aangetref kan word en tog ook by ongelowiges in die heidense wêreld voorkom? Dit is wel ' $n$ feit dat liefde altyd 'n moontlikheid is binne menslike saamwees. Die vraag is egter of só 'n 'geloof in die liefde' beskryf kan word as dié bepalende mag oor my lewe? Die antwoord is hoogstens 'n 'miskien' (Bultmann 1958:241).

Die 'regte' (en outentieke) vrae oor die liefde behoort nie liefde te bedoel as 'n geestelike en historiese fenomeen wat ek 'liefde' noem nie (Bultmann 1958:242). Ek vra nie na liefde in die algemeen wat hier en daar voorkom nie. Ek vra na die liefde waarmee ek liefgehê word. Is liefde wat ek per geleentheid in my lewe teengekom het, dan voldoende? As die antwoord hierop 'ja' is, moet ek ook die moed hê om soos Emil Brunner (1927:549) te sê dat ek iemand is wat liefhet, want die liefde word net in liefde ontvang en om liefgehê te word, beteken om ook lief te hê (Bultmann 1958:242, n. 1).

Indien ek egter net enkelinge kan uitsonder wat ek liefhet omdat hulle my liefhet, die eggenoot, 'n vriend, ensovoorts, is my liefde nie egte naasteliefde nie omdat dit ' $n$ liefde is wat uitsoek. In so 'n liefde speel ék 'n bepalende rol (vgl. Bultmann 1958:242, n. 2; Søren Kierkegaard 1924:48-65). In werklikheid het ek my naaste nie lief nie, omdat ek myself nie wil toelaat om die ander se liefde te ontmoet nie. Om hierdie liefde te ontvang is self ' $n$ handeling en hierdie handeling veronderstel geloof. Hierdie geloof word voortdurend deur wantroue versteur. Dat die liefde 'alles glo' (1 Kor 13:7) is nie iets wat ons uit ons eie regkry nie. Dit is juis hierdie wantroue wat ons op ons weg teëkom - 'n wantroue wat ons eie liefdeloosheid en die haat wat ons lewe kenmerk, bevestig (Bultmann 1958:242).

'n Geloof in die liefde is net moontlik as dit glo in 'n liefde wat wantroue onmoontlik maak, 'n oneindige liefde, God se liefde. Dit gaan nie om 'n idee oor God se liefde as 'n ewige eienskap van God wat 'n mens nie kan ken nie, maar met behulp waarvan jy wel 'n abstrakte idee van God kan vorm. Nee, 'n mens kan net aan God se liefde glo as die liefde 'n mens waarlik ontmoet in die werklikheid van jou menswees (Bultmann 1958:242). Hierdie daad van God se liefde vergewe my die feit van my liefdelose bestaan (Bultmann 1958:243). Dit is 'n geskenk van God wat my bevry van my verlede wat met haat gevul is en wat ek telkens weer in die hede inbring (Bultmann 1958:242). Liefde is dus net moontlik op grond van geloof wat die vergewing van sonde wat God se Woord aanbied, aanneem. Vergifnis is ' $n$ betoning van liefde wat bevry tot liefde (Bultmann 1958:242).
Die betekenis van die Christelike boodskap is dat God se liefde wat sonde vergewe, gekom het in Christus: 'Die liefde bestaan nie daarin dat ons God liefgehad het nie, maar daarin dat God ons liefgehad en God se Seun gestuur het as versoening van ons sonde' (1 Joh 4:10) ${ }^{20}$ (Bultmann 1958:243). Liefde word moontlik in die menslike bestaan net vir sover as wat mense hulle bestaan as nuut begrond in God deur Christus ervaar. Net soos wat Christelike geloof in God moontlik word deur Christus, so word ook die Christelike liefde moontlik 'in Christus'. Dan word die liefde 'n eskatologiese werklikheid - as 'n nuwe gebeurtenis in die geskiedenis (Bultmann 1958:243). Liefde volg uit herskepping op grond van die opstanding van Christus en die mens se deelkry in die geloof aan die sterwe en opstanding van Christus. ${ }^{21}$ Liefde is in hierdie sin dus nie 'n nuwigheid in die mensheidsgeskiedenis nie, maar wel dat dit dié nuwe gebod is omdat die mens 'in Christus' ' $n$ nuwe skepping is. Wanneer Christus die liefde van God 'n werklikheid maak in die wêreld van mense, word die liefde'n werklikheid (Bultmann 1958:243). Menslike liefde word gegrond daarin dat mense liefgehê word: 'Ek gee julle 'n nuwe gebod, dat julle mekaar liefhet op grond daarvan dat Ek julle liefhet sodat julle mekaar kan liefhê' (Joh 13:34); en: 'Dit is my gebod, dat julle mekaar liefhet omdat Ek julle liefhet' (Joh 15:12) (Bultmann 1958:243).

Twee dinge is belangrik om in te sien: ${ }^{22}$

- Die gebod om lief te hê kom van Jesus; die liefde wat ervaar word, kom van God; naasteliefde is die liefde van 'gelowiges in Christus'.

- Hierdie vergelykende (komparatiewe) uitsprake oor die aard van die 'Ich-Du'-verhoudings (tussen God, Jesus, gelowiges en die naaste) behoort nie uit die oog verloor te word nie, naamlik dat Jesus in liefdesverhouding met God gelewe het, dat die gelowige in liefdesverhouding met Jesus lewe en dat gelowiges in liefdesverhouding met hulle naaste is.

Deur lief te hê soos Jesus, ${ }^{23}$ dit wil sê gehoorsaamheid aan die gebod van naasteliefde en die vrymoedigheid (parrēsia) ${ }^{24}$ om in hierdie wêreld, elke dag en oomblik omdat elke oomblik

20.Vergelyk ook Romeine $5: 6$-8; 1 Korinthiërs $8: 1$-3; 2 Korinthiërs 5:14-16; Galasiërs 5:6 (Bultmann 1958:243, n. 1).

21.Bultmann (1958:243) stel dit soos volg: 'Liebe wird unsere Existenzmöglichkeit nur dardurch, daß wir unsere Existenz als durch Christus in Gott gegründete bzw. Neugegründete erfassen. Wie es christlichen Glauben an Gott erst gibt durch Christus, so auch christliche Liebe.'

22. Hierdie opmerkings is nie deel van Bultmann se opstel oor naasteliefde nie, maar 'n verduideliking op grond van Bultmann (1973:72-74) se kommentaar op 1 Johannes $4: 17-18$. Sy siening is dat die outeur van die 1 Johannes-brief die Evangelie van Johannes as basis gebruik het en dit in konteks van die outeur se 'kerklike tradisie' gebruik het (Bultmann 1973:1). Hierbenewens is die 'kerklike 'kerklike tradisie' gebruik het (Bultmann 1973:1). Hierbenewens is die 'kerklike
redaktor' verantwoordelik vir die enkele gevalle van 'apokaliptisering' in beide redaktor' verantwoordelik vir die enkele gevalle van 'apokaliptisering' in beide
die Evangelie van Johannes en die 1 Johannes-brief. So byvoorbeeld, suggereer die Evangelie van Johannes en die 1 Johannes-brief. So byvoorbeeld, suggereer
Bultmann (1973:72-73) dat die woorde in 1 Joh 4:17, 'ons het vrymoedigheid om Bultmann $(1973: 72-73)$ dat die woorde in 1 Joh 4:17, 'ons het vrymoedigheid om
te getuig' $[=$ parrēsia $=$ vertroue] in hierdie wêreld [en tō kosmō toutō]', verwys na te getuig' [= parrēsia = vertroue] in hierdie wêreld [en tō kosmō tout
'ons het parrēsia op die dag van oordeel [en tē hēmera tēs kriseōs]'.

23. Die Griekse demonstratiewe voornaamwoord 'daardie een' (ekeinos) in 1 Joh 4:17 ('soos Hý is, is ons ook in hierdie wêreld') kan net op Jesus dui (Bultmann 1973:72).

24.Die uitdrukking 'parrēsia' wat as 'vertroue' deur Bultmann (1973:72) vertaal word, het ' $n$ verreikende konnotasie. Na aanleiding van 1 Joh 4: 13 se vermelding van die Gees wat vir gelowiges gegee is, verstaan ek die vrymoedigheid wat gelowiges in die wêreld het (kyk Bultmann 1973:73) se rekonstruksie van 1 Joh 4:17 voordat in die wêreld het (kyk Bultmann 1973:73) se rekonstruksie van 1 Joh 4:17 voordat
die 'kerklike redaktor' die uitdrukking 'in die wêreld' ge-apokaliptiseer het deur die 'kerklike redaktor' die uitdrukking 'in die wêreld' ge-apokaliptiseer het deur
dit te verander na die 'dag van oordeel' (en tē hēmera tēs kriseōs), as verwysend na 'Jesus se afskeidswoorde' in Johannes 16:25 oor die onverskrokke 'getuienis' (parresia) van gelowiges in die wereld, omdat God die Gees as die 'parakleet' vir gelowiges gee om in die 'krisis' van die wêreld 'oorwinnend' te wees
(Joh 16:5-11) - 'en dit is die oorwinning wat die wêreld oorwin (kai autè estin hē nikè hē nikèsasa ton kosmon): ons geloof (hē pistis hēmōn) (1 Joh 5:4). 
die 'kritieke dag' vir beslissing en oordeel is ${ }^{25}$ is daardie gebeure waar die doel (teteleiōtai) van God se 'liefde-metons' (hè agape meth' èmōn) (1 Joh 4:17) realiseer. ${ }^{26}$ Naasteliefde waardeur die liefde van God en die liefde van Jesus deur ons vloei, is sonder vrees (fobos ouk estin en te agapē). God is liefde (1 Joh 4:8; 4:16). Vrees impliseer oordeel (ho fobos kolasin echei) (1 Joh 4:17). Liefde het niks met vrees of selfbelang te doen nie. Vrees gaan gepaard met oordeel (kolasis) (vgl. Bultmann 1973:73; Matt 25:46). Om bang te wees om gestraf te word, is 'n self-dienende ideaal. Dit is egter nie iets wat by God gevind word nie en dit mag ook nie die doel (telos) van ons vermeende naasteliefde te wees nie. Waarin is ons naasteliefde dan gegrond? Jesus se woorde volgens Johannes 3:15 dien as antwoord:

Só lief het God die wêreld gehad, met die gevolg dat God sy unieke Seun ${ }^{27}$ gegee het, sodat elkeen wat op Hom vertrou [in Hom $\mathrm{glo}$ ], nie verlore is nie maar in God se teenwoordigheid lewe..$^{28}$

In sy opstel oor naasteliefde beklemtoon Bultmann (1958:243) dat hierdie liefde 'n eskatologiese gebeure is. Die eskatologiese aard word uitgedruk met die verwysing na 'nuut' teenoor 'oud' (1 Joh 2:7-8):

Geliefdes, dit is nie ' $n$ nuwe gebod wat ek julle gee nie, maar eerder 'n ou gebod wat julle van die begin af gehad het. Hierdie ou gebod is die Woord wat julle hoor. Tog gee ek julle 'n nuwe gebod wat' $n$ werklikheid word in die Woord, want die duisternis verdwyn en die ware lig skyn reeds. (Bultmann1958:243)

Liefde begin by liefgehê word en gaan oor tot liefhê. Die uitspraak van die Johannese Jesus, 'bly in die liefde', veronderstel om liefgehê te word, en dit impliseer dan ook om te bly in die liefde as liefhê (Joh 15:9-10). Die een is net ' $n$ moontlikheid waar die ander een ' $n$ werklikheid is. Naasteliefde is volgens Bultmann (1958:243) egte en ware liefde wanneer dit terselfdertyd God se liefde is. Net dan is die liefde moontlik (vgl. Brunner 1927:550; Bultmann 1958:243 n. 2; Kierkegaard 1924:113; 118).

Net as liefde van God kan die liefde die natuurlike lewensrigting van mense omkeer - 'n omkeer van die mens se self en die mens se ervaring. Net wanneer mense hierdie

25.Volgens Bultmann (1973:74) het die "kerklike redaktor' die eskatologiese begrip 'straf' (kolasis) 'gehistoriseer', net soos die redaktor in Johannes 3:19 en 5:24 met die begrip 'oordeel' (krisis) gemaak het. Die voor-redaksionele bedoeling kom die begrip 'ordee (krisis) gemaak het. Die voor-redaksionele bedoeling kom egter ooreen mat (hulle 'elkeen wat glo, het die ewige lewe').
'elaste) in die lewe oorgegaan' (vgl. ook Joh 3:14:

26.Die Griekse uitdrukking teteleiōtai is in die grammatikale vorm van 'n perfektum passief. Die subjek van die handeling is God. Die betekenis is om die doel te bereik (Newman 1971:180). Die Aktionsart van die perfektum is om 'n toestand van feitelikheid uit te druk.

27.Die Griekse uitdrukking monogenēs beteken die 'enigste in dié soort' (Louw \& Nida 1988:591).

28.Ek verstaan die uitdrukking 'om die ewige lewe te hê' (echē zōēn aiōnion) (Joh 3:16) as die 'goue era', na aanleiding van Philo Judaeus, De mutatione nominum \$267. Wat die gebruik van hierdie 'tyd' as 'goddelike tyd' in onderskeidelik die Evangelie van Johannes en die Evangelie van Matteus, kyk my verwysings (Van Evangelie van Johannes en die Evangelie van Matteus, kyk my verwysings (Van Aarde 2011b:45, n. 34; n. 35; 2011b:3 of 7) na Neyrey en Rowe (2008); en Kreuze (2005:110-114). Volgens Philo is die 'ewige lewe' daardie tipe tyd wat nie gemeet word by the revolutions of son and moon, but something truly mysterious, strang and new, other than the realm of sight and sense, having its place in the realm of the incorporeal and intelligible, and to it belongs the model and archetype of time, eternity and aeon' (in Philo Judaeus De mutatione nominum \$267, in Cohn en Wendland 1962:156-203; kyk Van Aarde 2011b:45, n. 34; n. 35; Van Aarde 2011c) liefde van God aanvaar, kan die liefde vir die naaste egte liefde wees - nie die liefde (kata sarka = volgens die natuurlike mens se begeertes) wat uitsoek wie om lief te hê omdat daar wedersyds goeie gevoelens bestaan nie, maar liefde (kata pneuma $=$ volgens die Gees van God) wat blywend is en nie tipies menslik van verbygaande aard (sarkikos) is nie (1 Kor 13:8) (Bultmann 1958:244). Volgens Paulus ${ }^{29}$ is die liefde van God 'in Christus Jesus ons Here' die 'liefde van Christus' (he agape tou Christou) (Rom 8:35) ${ }^{30}$ wat deur niks sigbaar of onsigbaar, in lewe of in dood, van die gelowige weggeneem kan word nie (Rom 8:35-39). Dit is die liefde wat God in die harte van gelowiges uitstort deur God se Heilige Gees aan gelowiges te gee (Rom 5:5). Dit is hierdie liefde wat as 'eskatologies' verstaan moet word. Christus het die lewe sonder liefde afgesterf. Vir die lewe in liefde is Christus uit die dood opgewek (Rom 5:10-11). Dit is dié liefde wat nooit sal faal nie (he agapè oudepote piptei) (1 Kor 13:8) - die liefde wat nóú bly (nuni menei)- dus in kwaliteit nog méér (meizón) as geloof en hoop (1 Kor 13:13), omdat geloof (en hoop) nog in die liefde voortgesit word (pistis di' agapēs energoumenē) (Gal 5:6).

Net wanneer die 'liefde van Christus' ' $n$ mens dring en beheers (2 Kor 5:14), ken jy die ander nie meer kata sarka, 'na die vlees' (sowel die voor- as die nadele wat deel van die natuurlike bestaanswyse is) nie (2 Kor 5:16). In die lewe kata pneuma, 'volgens die Gees van God', word die natuurlike wantroue en haat van die mens oorwin. Dan begryp mense dat almal, hulleself én die naaste, in dieselfde situasie verkeer (Bultmann 1958:244) - gedetermineer deur hulle verganklikheid en begeerte om die menslike eiewaarde te dien. Alles wat nie uit geloof voortspruit nie, is sonde (Rom 14:23). Beide - ek én my naaste - is sondaars en beide - ek én my naaste - is begenadigdes (Bultmann 1958:244). Vir beide - vir my én vir my naaste - is die vergifnis in Christus beskikbaar. Só sien gelowiges as begenadigdes 'die Ander': as mense in wie hulle die liefde van Christus ontmoet (vgl. Brunner 1927:551).

Ons het mense lief omdat ons in hulle liefde glo, ook al sien ons dit nie en ook al glo hulle nog nie self daarin nie. Ons as gelowiges het daarom nie net ander mede-gelowiges lief nie, want ons vra nie wie as ons naaste kwalifiseer nie. Deur te glo, bevry ons die ander tot liefde (Bultmann 1958:244). Ons 'glo' as 't ware in mense - ons draai nie ons rug op mense nie en ons skryf hulle nie af nie. Hierdie 'geloof in mense' is nie 'n optimistiese oortuiging dat die mensheid goed is nie. Dit word begrond in die ontvang van vergifnis (Bultmann 1958:244). As dit nie so sou wees nie, sou ons 'liefde' gegrond wees in ons eie besluit en prestasie. Liefde as prestasie is nie liefde nie, maar is ' $n$ holklinkende, luidende metaal en 'n klinkende simbaal (1 Kor 13:1): 'Alles wat nie uit die geloof is nie, is sonde' (Rom 14:23) (Bultmann 1958:244).

29.Die res van hierdie paragraaf kom nie in Bultmann se opstel oor naasteliefde voor nie. Dit is wel ' $n$ verduidelikende kommentaar op sy siening.

30.Sekere manuskripte (Vaticanus en dié deur Origines gebruik) lees egter: 'van God in Christus'. 
Die ander kant is ook waar: geloof kan net eg wees in liefde (Gal 5:6). Mense se liefde vir God is net ware liefde as dit tegelyk ook liefde tot die naaste is (Bultmann 1958:244). Hierdie liefde berus op die ontvang van die vergifnis van sonde. Die suiwerste uitdrukking hiervan is in die bereidheid om te vergewe. Vergewing keer die self-liefde radikaal om. In vergewing is dit duidelik dat die liefde werksaam is. As daar die bereidheid is om te vergewe, kom 'n mens agter dat daar eintlik niks is om te vergewe nie. Die ander is reeds vergewe deur God, in Christus. Dan word die bereidheid om te vergewe daardie geloof in die naaste wat die naaste én myself bevry om lief te hê (Bultmann 1958:244).

Bultmann sluit sy opstel oor die naasteliefde af met 'n vertaling van 1 Johannes 4:19-21 (kyk later). Om hierdie sitaat as hoogtepunt van Bultmann se verstaan van die Christelike etiek goed te verstaan, is dit nodig om - méér as wat Bultmann dit self gedoen het - die Christelike naasteliefde in die algemene eerste-eeuse wysheid van die Stö̈synse etiek in te bed. Dit is egter ook nodig om eerstens die Stoa-etiek te verstaan as 'n transformasie van die voor-Stoa Griekse wysheid, naamlik dat etiek nie in ideologie behoort op te gaan nie, en tweedens om die onderskeidingskenmerk tussen die etiek in die Griekse wysheid en die Christelike etiek ook raak te sien.

\section{Stoïsynse etiek}

Vir die Stoïsyne was dit die konvensie om Plato se Republiek (bv. Brown 2011) as templaat te gebruik hoe om eties te handel ten opsigte van die vraag wat is goed en wat is sleg, wat maak jou siek en wat maak jou gesond (Schofield 2003:240). Hierdie konvensie het as antwoord dat nie een van hierdie uiterstes (siek-gesond; sleg-goed) op sigself die ideaal kan wees nie. Daar is altyd keuses om uit te oefen, byvoorbeeld Cicero (volgens Lactantius, raadgewer van keiser Konstantyn, in sy Diuinae Institutiones $V$, 16) sê: Rome kon alleen 'n empire geword het deur Rome se voordeel na te jaag en nie om te gee hoeveel onreg daarmee gepaard gegaan het nie. 'n Keuse teen hierdie konvensie sou die volgende wees, sê Cicero: as 'n slawe-eienaar 'n slaaf het wat weggeloop het, dit wil sê ontrou was, of 'n huiseienaar het ' $n$ huis wat vol kieme en peste is, en die eienaar wil van die slaaf of die huis ontslae raak en hy maak die probleem (ontrouheid of siekte) bekend, gaan hy 'n minder goeie prys kry. Die gevolg is dat hy tegelyk as 'n goeie mens beskou sal kan word en volgens konvensie as 'n dwaas gereken word (Cicerio, in Lactantius, Div. Inst. V, 16). Die keuse is dus om die 'goddelike oikoiesis' ${ }^{31}$ se belang te bevorder of om filantropie na te streef (Schofield 2003:252-253). Is jy moreel of is jy 'n dwaas? Crisippius (Diogenes Laertius vii.89) sê: jou keuses en oordele kan meer op die geheel gerig wees as op die dele, dit wil sê, meer op die belang van die instelling as op die individu. As jy volgens die konvensie handel, is die instelling die belangrikste. As die individu belangriker word, sal jy onkonvensioneel wees. Dit sou beteken dat jy jouself

31.Die Stö̈synse begrip "God se huishouding van die wêreld' (dioikesis theia tou kosmou) (kyk Shaw 1985:29) het die polis-ideologie en dié se hiërargie en eksploiterende sisteem getransformeer (kyk Van Aarde 2014b). eerder skade doen as om deel te neem aan die onregverdige oorlog van 'n tiran. Dit is die kennis van ervaring wat jou help om vir die onkonvensionele te kies. Daarom sê Epictetus (Dissertationem III.24.84-87): jou naaste is nie jou besitting nie. Die instelling, die sisteem, die ideologie is die plek waar jy asemhaal, maar dit is nie die instelling, sisteem of ideologie wat jou keuses behoort te bepaal nie (Schofield 2003:255).

Epictetus en Seneca is voorbeelde wat die Stoïsynse etiese sisteem getransformeer, as' $\mathrm{t}$ ware gedekonstrueer het. Dit kan veral gesien word in hoe hulle die konvensie van resiprositeit (naasteliefde) anders verstaan het. Jy behoort nie teenoor iemand anders so op te tree om dividende te verwag nie. Terugkerende selfbelang behoort nie die doel te wees nie. Die balspele in die Olimpiese Spele is 'n voorbeeld (Seneca, De beneficii 11.17.3-4, verwysend na Chrisippius). Die een party gooi die bal na die ander so hard soos jy kan sodat die ander nie maklik die bal kan teruggooi en die spel op 'n simmetriese wyse kan voortgaan nie. Jy probeer so hard gooi om die ander te verneder sodat die ander die bal nie kan teruggooi nie - en jy die 'oorwinnaar' is. Werklike oorwinning is dat jy eerder die bal op so 'n 'tedere' wyse na die ander gooi, dit eintlik in die ander se hand sit, sodat die ander dit kan teruggee en jy geen doel het om die ander te verneder of te oorwin nie (Schoffield 2003:256). Dit is wat die ware strategie van naasteliefde is. Dit is hoe jy ander mense behoort te help.

Die naasteliefde wat Bultmann by die gelowige 'in Christus', op grond van die Nuwe-Testamentiese gebod raaksien en beskryf, deel hierdie Stoïsynse opvatting. Laasgenoemde kan nie as 'n ideologie gesien word nie. Inteendeel, dit getuig van liefde vir die ander wat voortspruit uit die 'Ich-Du'-relasie. Dit is nie gegrond in die siening 'die doel heilig die middel' nie. Dit is nie die nastreef van ' $n$ ideaal wat in werklikheid 'n diens aan my self is nie. Liefde het nie resiprositeit as doel, sodat liefhê liefde wil terugontvang nie. Dit is nie voorwaardelik omdat mense eers aan my voorkeure moet voldoen nie. Dit is ook nie liefde ter wille van die 'regte politieke' redes nie.

Die Christelike naasteliefde is ingebed in die algemene eerste-eeuse Griekse wysheid wat in die Jesus-tradisie en in Paulus- en Johannes-tradisie - hoewel met eie karakeristiekeneerslag gevind het.

Wat is dan die verskil tussen Christelike etiek en Griekse wysheid? Beide sien die mens as gebonde, soos 'n slaaf aan kettings, wie se lot bepaal word deur die gang van die natuur. Beide beklemtoon die goddelike sorg van die kosmos. Die 'nuwe' in die Christelike gebod is egter nie dat liefhê voortspruit uit die feit dat God/Zeus 'eerste' liefgehad het nie. By die Stoïsyne en in die Jesus-tradisie is die begronding van die liefde in hierdie opsig dieselfde. Wat 'nuut' in die Christelike liefdesgebod is, is die begronding in die sterwe én die opstanding van Jesus Christus (vgl. Van Aarde 2013b). Soos die Christus, so die Christus-volgeling; soos Christus, so jy self; soos jouself, so jou naaste; soos vir jou naaste, so vir God. Die distinktiewe van Christelike naasteliefde is dat 
liefde vir jou naaste liefde is soos jy jou innerlike (psuchē) self liefhet. Paradoksaal gee jy jou 'self' (psuchē) prys en jy red jou 'self' (psuchē) (Mark 8:35).32

Nou kan ons Bultmann (1973:238) eers regtig verstaan as hy die karakteristieke van die Christelike etiek aan die hand van die Jesus-logion, 'jy moet jou naaste liefhê soos jy jouself liefhet', beskryf. Met ander woorde, wie hulleself liefhet, weet hoe hulle wil hê dat die ander hulle sal liefhê; wie die ander liefhet, weet ook wat hulle aan die ander behoort te doen. Nou kan ons ook Bultmann se afsluiting van sy opstel oor die naasteliefde met die vertaling van 1 Johannes 4:19-21 beter in konteks verstaan:

Ons het lief ${ }^{33}$ omdat God ons eerste ${ }^{34}$ liefhet. Wanneer ons sê, 'ek het God lief', en ek haat my broer [en suster], is ek 'n leuenaar. ${ }^{35}$ Diegene wat hulle broer [en suster], wat hulle kan sien, nie liefhet nie, kan nie vir God liefhê wat hulle nie kan sien nie. En dít is die gebod wat ons van Hom [Christus] ${ }^{36}$ het, naamlik dat ons wat God liefhet, ook ons broer [en suster] liefhet. (1 Joh 4:19-26; eie vertaling)

\section{'n Raamwerk van Bultmann se teologiese hermeneutiek}

Bultmann (1958) se verstaan van die Christelike gebod van naasteliefde as uitdrukking van die gelowige 'in Christus' se eksistensiale Dasein-bestaan, is kongruent met sy teologiese hermeneutiek. Laasgenoemde kan met die volgende uitgangspunte opgesom word..$^{37}$

Bultmann het geen probleem gehad om met 'n radikale en konsekwente historiese benadering die Bybel te ondersoek nie. Wat wel in sy histories-kritiese eksegese nie uit die oog verloor behoort te word nie, is sy onderskeid tussen die begrippe 'historisch' en 'geschichtlich'. Wanneer geskiedenis uitgelê word as moontlikhede vir die verstaan van die

32. Hierdie 'komparatief' in Jesus se naasteliefde-tradisie word in die Evangelie van Thomas $(25: 1-2)$ beskryf as liefde vir die naaste soos vir die self ( $p$ suchē) deurdat jy dit soos die appel van jou eie oog beskerm (vgl. Funk 1985:126; 1990:196-197).

33.Bultmann (1973:75), in sy kommentaar op 1 Johannes 4:19, verkies om op grond van 1 Johannes 4:7 ('elkeen wat liefhet, is uit God gebore'), 'liefhê' hier as indikatie eerder as imperatief te vertaal.

34. Die uitdrukking 'eerste' is ' $n$ temporele komparatief wat op vorige gebeure dui en dit behoort dus nie verstaan te word as 'in die eerste plek' nie (Bultmann 1973:75, n. 3)

35.Die werkwoordelike nomen 'leuenaar'/'om te lieg' is multivalent en kan twee dinge beteken: om nie die waarheid te praat nie én om jou van die werklikheid van God af te skei (Bultmann 1973:76).

36. Dit is moontlik om die persoonlike voornaamwoord te verstaan as verwysend na God, soos ook in 1 Johannes 5:3 waar gesê word, 'dít is God se liefde dat ons "sy" ( "sy" (= God se) geboie' bewaar' (per implkasie by Bultmann 1973.77). Dit is ook moont ik on 'gebooie' as ' $n$ implisiete verwysing na die dekaloog as sodanig te sien. Ek verkies egter om spesifek die betrokke vornaamword in 1 Johannes 4:21 te interpreteer as verwysend na Jesus as die Christus. Ek het twee redes. In die eerste plek, na aanleiding van 1 Joh 5:3 se frase 'en sy gebooie is nie swaa [om te dra] nie' - ten spyte van die feit dat hierdie uitdrukking onder andere ook by Philo ('De decalogo' en 'De specialibus legibus') voorkom (Bultmann 1973:77, n. 14) - sien ek in hierdie woorde ' $n$ toespeling op beide Jesus se samevatting van die dekaloog (Mark 12:29-31//Matt 22:37-40//Luk 10:26-27// Didache 1:2// ThomasEv 25:1-2//Barnabas 19:5) en Jesus se woorde dat hierdie samevatting (liefde vir God én vir die naaste [broer, volgens die ThomasEv]) die 'grootste' gebod is (Mark 12:31c) en in die 'sentrum' staan/'dit waaraan die ander hang' (Matt 22:40). In die tweede plek sien ek hierin ' $n$ toespeling op die Jesus-spreuk (in Matt 11:29-30 en ThomasEv 90:1-2) dat die juk van Jesus se wetsverstaan nie 'n swar las is nie, want Jesus, volgens Matteus, is barmhartig (prous) en nederig van hart (tapeinos te- kardia) hart (tapeinos te kardia), en volgens Thomas, is Jesus se koningskap nie hard nie algemene wysheid in gedagte wat ook in Jesus Sirag 51:26-27 voorkom.

37.Kyk onder andere die geraadpleegde literatuur aan die einde van die hierdie eerste artikel en in die besonder Van Aarde (2011a; 2014a:251-271). eie eksistensie, dan is outentieke bestaan (= om te glo) onafhanklik van 'n gebondenheid aan die wêreldbeeld van 'n bepaalde tyd, en dan veral die antieke teïstiese driedimensionele mitologiese wêreldbeeld.

Onder 'historisch' verstaan Bultmann die gewoon historiese feitelikheid van 'n gebeurtenis. As die gebeure in die voor-Kopernikaanse (d.w.s. die 'Bybelse' tyd, asook die ontstaanstyd van die klassieke Christelike belydenisskrifte) dan kan die teoloog nie anders as om hierdie mitologie in ag te neem nie - anders vind 'n sacrificum intellectum plaas. Die begrip 'geschichtlich' verwys na die eksistensiële konsekwensie van so 'n gebeurtenis. Die 'kerugma van die evangelie' (kyk my bespreking van Matt 26:13 in Van Aarde 2015) fokus nie op die Historie nie, maar op die Geschichte. Hierdie verstanende ontmoeting met die geskiedenis is op 'n beslissing (Entscheidung) afgestem - nie egter net één besluit en dan afgehandel nie! Beslissing en weer beslissing, oor en oor, en só word die geskiedenis telkens met nog 'n volgende beslissing in die toekoms vír God én teen selfbelang, wéér en wéér, tot einde gebring (uitgedruk met die begrip 'Entweltlichkeit').

Volgens Bultmann is die persoon en die geskiedenis van Jesus vir die kerugmatiese toespreke van geen betekenis nie. Om na die historiese Jesus agter die kerugma te vra, het nie die bedoeling om geloof te wek nie. Dit is wel 'n ervaarde gegewe dat Jesus Christus as die 'einde van die geskiedenis' bitter moeilik in ons tyd-ruimtelike wêreld geïnternaliseer en in geloof geleef kan word. Met Jesus het die geskiedenis tot einde gekom het. Gelowiges leef radikaal vanuit liefde en vergeld nie sigself (vgl. sy begrip 'Entapokalyptizierung') nie, en het nie 'n ywer vir nasionale en sosiale ideale nie (vgl. sy begrip 'Entnazisierung').

Bultmann hou vas aan die extra nos van God se interaksie (van buite) met die mens. Die genadedaad van God se versoening van die mens met God geskied in en deur dié historiese mens, Jesus van Nasaret. Hierdie Gods-ontmoeting-in-die-mensJesus noem Bultmann die mitologiese res, dit is naamlik dat God extra nos die mens pro nobis [tot ons] wend. Hierdie genadedaad word in die woord wat nóú verkondig word, ervaar. En die geloof van die hoorder is niks anders nie as die antwoord op dié appèllerende woord. Die oproep van God geskied deur middel van spesifieke historiese gebeure, in die mens Jesus wat aan ons verkondig word as die Christus en die Kurios.

\section{Die 'wet van Christus' of die 'wet van die natuur'?}

Die konteks van kerkwees in Suid-Afrika vandag noodsaak vrae en antwoorde oor die onderskeidende kenmerke van die Christelike etiek. In 2011 het die Nederduitsch Hervormde Kerk van Afrika (NHKA) op 'n buitengewone Algemene Kerkvergadering (AKV) vir dae lank gedebatteer of 'n mens moet jammer sê of nie (skuldbelydenis maak), oor onreg wat onder Apartheid gepleeg is en sodoende die beeld van God 
in die verontregte mens aangetas het (vgl. NHKA 2010; 2011; 2012).$^{38}$ Op grond van sy verstaan van Christelike etiek (en daarby ook Luther, Calvyn, Barth en Brunner se verstaan van Christelike etiek), sou Bultmann 'n ernstige probleem gehad het met 'n dae lange debat oor die geldigheid van die vraag of die ander 'beelddraer van God' genoem mag word.

Dit is ook epistemologies onwaarskynlik dat iemand vanuit 'n 'Ich-Du' relasionele etiek sinvol kan kommunikeer met iemand wie se etiek blindelings, bewustelik of onbewustelik, gedryf word deur óf die abstrakte outoriteit van 'n ideologies georiënteerde leiersfiguur óf deur die ideologie self.

So 'n debat is futiel en gedoem tot mislukking. Kompromisse bied ook nie outentieke oplossings nie (vgl. Van Aarde 2013a).

Die Lutherse (en Bultmann s'n) siening dat daar nie iets soos sakrale versus profane etiek is nie, onder andere gebaseer op die uitspraak in Romeine 2:15 dat God se wet in die hart van alle mense geskryf staan, laat sommige ortodokse teoloë die sogenaamde skeppingsordeninge nie waardeer as die 'anderkant' van die 'wet van Christus' nie. Dit gee hulle die reg om etnisiteit, ras, seksualiteit, familie en regering te sien as 'strukture van bestaan' (kyk Braaten 2011:3-15; Pearson 2011:39-63). Daar is egter ook daardie Lutherse teoloë, soos onder andere Rudolf Bultmann, wat na aanleiding van Romeine 10:4 besef dat Christus vir elkeen wat glo en in die regte verhouding met God gestel is, die einde (telos) van die wet (van die natuur) is.

Die wet (van God) word in één woord saamgevat: jy moet jou naaste liefhê soos jouself (Gal 5:14). Liefde kan daarom die naaste nie kwaad aandoen nie. Naasteliefde is alles wat die wet veronderstel (Rom 13:10). ${ }^{39}$

\section{Erkenning Mededingende belange}

Die outeur verklaar hiermee dat hy geen finansiële of persoonlike verbintenis het met enige party wat hom nadelig of voordelig kon beïnvloed het in die skryf van hierdie artikel nie.

\section{Literatuurverwysings}

Aristoteles, [4 BCE] [1957] 1964, 'Politica', in W.D. Ross (red.), Aristotelis politica 1252a1-1342b-34, Clarendon Press, Oxford.

Augustinus, [354-430 CE] [1888] 2009, 'Tractatus VII.8' (Homily 7 on the First Epistle of John 1 John 4:4:4-12), in P. Schaff (ed.), From Nicene and post-Nicene fathers, first ser., vol. 7, transl. H. Browne, Christian Literature Publishing Co., Buffalo, revised and edited for New Advent by K. Knight, viewed 27 July 2014, from http:// www.newadvent.org/fathers/170207.htm

Beutel, A., 2012, Gerhard Ebeling: Eine biographie, Mohr Siebeck, Tübingen.

38.Besluit 54 van die 69 e AKV: 'Die 69 e AKV maak in die lig van die 68 e AKV se besluit dat dit verkeerd was om ' $n$ bepaalde regeringsbeleid (apartheid) goed te praat, onomwonde die uitspraak dat apartheid nie teologies geregverdig kan word nie. Die kerk verwerp sy goedkeuring van apartheid omdat dit:

- in stryd is met die evangelie van Jesus Christus

- gebaseer is op die idee van onderlinge onversoenlikheid

- onreg sanksioneer

- die beeld van God in mense aantas'.

39.My vertaling van hē agapē tó plēsion kakon ouk ergazetaim plēróma oun nomou hē agapē (Rom 13:10).
Braaten, C.E., 2011, 'A Lutheran affirmation of the natural law', in R.C. Baker \& R.C. Ehlke (eds.), Natural law: A Lutheran reappraisal, pp. 3-15, Concordia Publishing House, St. Louis, MO.

Brown, E., [2003] [2009] 2011, 'Plato's ethics and politics in The Republic', in E.N. Zalta (red.), Stanford encyclopedia of philosophy, viewed 26 July 2014, from http:// plato.stanford.edu/archives/win2011/entries/plato-ethics-politics

Brunner, E., 1927, Der Mittler: Zur Aufgabe der Christologie, Verlag J.C.B. Mohr (Paul Siebeck), Tübingen.

Bultmann, R., [1930] [1933] 1958, 'Die christliche Gebot der Nächstenliebe', in R. Bultmann (red.), Glauben und Verstehen: Gesammelte Aufsätze, Erster Band, Dritte, unveränderte Auflage, pp. 229-244, Verlag J.C.B. Mohr (Paul Siebeck), Tübingen [Oorspronklik in Frans, in Revue d'Histoire et de Philosophie religieuses, 1930, pp. 222-241].

Bultmann, R., [1967] 1973, The Johannine epistles: A commentary on the Johannine epistles, transI R.P. O'Hara, L.C. McGaughy \& R.W. Funk, Fortress Press, Philadelphia (Hermeneia - A Critical and Historical Commentary on the Bible).

Casper, B., [1967] 2002, Das dialogische Denken. Franz Rosenzweig, Ferdinand Ebner und Martin Buber, überarbeitete und erweiterte Neuauflage, Verlag Karl Alber, Freiburg.

Davies, G.S., 1991, 'Et quod vis fac: Paul Ramsey and Augustinian ethics', Journal of Religious Ethics 19(2), 32-69.

Diogenes Laertius, [3 CE] [1853] 2008, 'Diogenes Laertius', in C.D. Yonge \& K. Seddon (reds.), The lives and opinions of eminent philosophers, revised version of Book Seven, pp. 112-118 [Cleanthes], pp. 119-121 [Spaerus], Lulu, Hertfordsshire, viewed 11 April 2014, from http://www.lulu.com

Duling, D.C., [2003] 2008, “"Whatever gain I had?": Ethnicity and Paul's selfidentification in Philippians 3:5-6', HTS Teologiese Studies/HTS Theological Studies 64(2), 799-818. http://dx.doi.org/10.4102/hts.v64i2.58

Ebeling, G., [1961] 1969, 'Hauptprobleme der protestantische Theologie in der Gegenwart: Anfragen an die Theologie', in G. Ebeling (red.), Wort und Glaube, Band II: Beiträge zur Fundamentaltheologie und zur Lehre von Gott, , pp. 56-71, Mohr Siebeck, Tübingen.

Epictetus, [1-2 CE] [1916], Dissertationem Epicteteum sive ab Arriano sive ab aliis digestarum fragmenta, in H. Schenkl (red.), Teubner Verlag, Leipzig, pp. 455-460, 462-475.

Epictetus, [1-2 C.E.] [1925] 1998, Epictetus: The discourses as reported by Arrian Books I-II, vertal. W.A. Oldfather, Harvard University Press, Cambridge (Loeb Books I-II, vertal.
Classical Library).

Fiensy, D.A., 2007, Jesus the Galilean: Soundings in a first century life, Gorgias Press, Piscataway.

Funk, R.W. (ed.), 1985 New Gospel parallels: Volume two-John and the other gospels, Fortress Press, Philadelphia (Foundations \& Facets), p. 126.

Funk, R.W., 1990, New gospel parallels, Vol. 12: Mark, rev. edn., Polebridge Press, Sonoma (Foundations \& Facets).

Gerstenberger, E.S., 2014, 'Sensitivity towards outsiders in Old Testament theologies', in J.' Kok, T. Nicklas, D.T. Roth \& C.M. Hays (eds.), Sensitivity towards theologies, in J. Kok, T. Nicklas, D.T. Roth \& C.M. Hays (eds.), Sensitivity towards the New Testament and early Christianity, Mohr Siebeck, pp. 27-40, Tübingen. the New Testament and early Christianity, Mohr Siebeck, pp. 27-40, Tübin
(Wissenschaftliche Untersuchungen zum Neuen Testament 2. Reihe, 364),

Heidegger, M., 1927, Sein und Zeit, Max Niemeyer Verlag, Halle.

Kierkegaard, S., [1890] 1924, Das Leben und Walten der Liebe, vertal. A. Dörner \& C. Schremp, E. Diederichs Verlag, Jena (Søren Kierkegaard Erbauchliche Reden, 4).

Kreuzer, J., 2005, 'Zeit- und Geschichtsbild', in J. Zangenberg (red.), Neues Testament und Antike Kultur, vol. 3, Weltauffassung - Kult - Ethos, Neukirchener Verlag, Neukirchen-Vluyn, bl. 110-114.

Lactantius, [c. 240 CE - c. 320 CE] 2003, Divine institutes [Diuinae institutiones], vertal. A. Bowen \& P. Garnsey, Liverpool University Press, Liverpool, pp. 36-38.

Liedboek van die kerk: Vir gebruik by die erediens en ander byeenkomste, 2001, NG Kerk-Uitgewers, Kaapstad.

Longenecker, B., [1998] 2001, Triumph of Abraham's God: The transformation of identity in Galatians, A\&C Black Publishing, London.

Louw, J.P. \& Nida, E.A. (eds.), 1988, Greek-English lexicon of the New Testament based on semantic domains, Volume 1: Introduction and domains, United Bible Societies, New York, NY.

Luther, M., [1529] 1826, Samtliche Werke, Erlangen Ausgabe, Band VII, 147, Heyder Verlag, Erlangen-Frankfurt.

Malina, B.J., 2008, 'Neighbor', in New Interpreter's Dictionary of the Bible, viewed 04 August 2014, from http://www.philosophy-religion.org/living/6.pdf, http://www. philosophy-religion.org/reflections/pdfs/Sermon25A-2008.pdf

Malina, B.J. \& Neyrey, J.H., 1996, Portraits of Paul: An archaeology of ancient personality, Westminister John Knosx Press, Louisville, KY.

Meier, J.P., 2009, A marginal Jew: Rethinking the historical Jesus, volume four: Law and love, Yale University Press, New Haven, CT. (The Anchor Yale Bible Reference Library).

Nederduitsch Hervormde Kerk van Afrika (NHKA), 2010, Besluitebundel van die 69e Algemene Kerkvergadering, Argiefbewaarplek van die Nederduitsch Hervormde Kerk van Afrika, Pretoria.

Nederduitsch Hervormde Kerk van Afrika (NHKA), 2011, Notule van die Buitengewone Algemene Kerkvergadering, Argiefbewaarplek van die Nederduitsch Hervormde Kerk van Afrika, Pretoria.

Nederduitsch Hervormde Kerk van Afrika (NHKA), 2012, Agenda van ' $n$ buitengewone vergadering van die Moderamen, 27 Augustus 2012, Argiefbewaarplek van die Nederduitsch Hervormde Kerk van Afrika, Pretoria. 
Newman, B.M., 1971, A concise Greek-English dictionary of the New Testament, United Bible Societies, London.

Neyrey, J.H. \& Rowe, E., 2008, 'Telling time in the Fourth Gospel', HTS Teologiese Studies/HTS Theological Studies 64(1), 291-320. http://dx.doi.org/10.4102/hts. v64i1.24

Pearson, T.D., 2011, 'Luther's pragmatic appropriation of the natural law tradition', in R.C. Baker \& R.C. Ehlke (eds.), Natural law: A Lutheran reappraisal, pp. 39-63, Concordia Publishing House, St. Louis, MO.

Philo Judaeus, [20 BCE - 50 BCE] [1937], 'De decalogo' (On the decalogue); 'De specialibus legibus' (On the special laws), vertal. F.H. Colson, Loeb Classical Library.

Philo Judaeus, [20 BCE - 50 BCE], De mutatione nominum ['On the change of names'] $\S 267$, in L. Cohn \& P. Wendland (reds.), [1902] 1962, Philonis Alexandrini opera quae supersunt, vol. 4, bl. 156-203, De Gruyter, Berlin.

Plato [5-4 BCE] [1900] 1967, 'Crito', in J. Burnett (red.), Platonis opera, vol. 1.43a-54e, Clarendon Press, Oxford.

Schofield, M., 2003, 'Stoic ethics', in B. Inwood (ed.), The Cambridge Companion to the Stoics, pp. 233-256, Cambridge University Press, Cambridge.

Seneca, Lucius Annaeus, [c. 4 BCE] 1925, 'Epistula 95: On the usefulness of basic principles', in Annaei Senecae ad Lucilium epistuale (Epistles 93-124), vertal. R.M. Gummere, pp. 78-7, Harvard University Press, Cambridge, 9 (Loeb Classical Library, Seneca, VI).

Seneca, Lucius Annaeus, [c. 4 BCE] 1928-1932, 'De benificii' ('On the acts of benefaction'), in Moral essays, vertal. J.W. Basore, Harvard University Press, Cambridge (Loeb Classical Library).

Seneca, Lucius Annaeus, [c. 4 BCE], 2003, 'De Otio. De brevitate vitae', in G.D. Williams (red.), Cambridge University Press, Cambridge, pp. 4-12.

Shaw, B.D., 1985, 'The divine economy: Stoicism as ideology', Latomus 44/1, 16-54, Societe d'Etudes Latines Bruzelles, viewed 31 March 2014, from http://www.jstor. org/stable/41543542

Singer, I., 2009, The nature of love 3: The modern world, The MIT Press, Cambridge. Smith, J.J., 2006, 'Emil Brunners theology of relevation', Landas 20, 22-53.
Van Aarde, A.G., 2011a, 'Rudolf Bultmann: Sy mees invloedryke bydrae in die 20ste eeu: "Urchristentum", "Jesus", "Johannes"- kommentaar?', HTS Teologiese Studies/Theological Studies 67(3), Art. \#1076, 7 pages. http://dx.doi.org/10.4102/ htudies/Theologic

Van Aarde, A.G., 2011b, 'A cameo on eschatology and apocalypticism', in '“On earth as it is in heaven": Matthew's eschatology as the kingdom of the heaven that has come', in J G an der Watt (red), Eschatology of the New Testament and has come', Untersuchungen zum Neuen Testament 2. Reihe, 315).

Van Aarde, A.G., 2011c, 'Regeneration and resurrection in Matthew - Peasants in campo hearing time signals from scribes', HTS Teologiese Studies/Theological Studies 67(3), Art. \#1012, 7 pages. http://dx.doi.org/10.4102/hts.v67i3.1012

Van Aarde, A.G., 2013a, "n Postliberale perspektief op 'n ekklesiologiese modaliteit as 'n ecclesiola in ecclesia - heroriëntasie in die Nederduitsch Hervormde Kerk van Afrika', HTS Teologiese Studies/Theological Studies 69(1), Art. \#2012, 14 pages. http://dx.doi.org/10.4102/hts.v69i1.2012

Van Aarde, A.G., 2013b, 'Faith as an exceptional religious state of consciousness: A pragmatic-linguistic reading of Romans 12', paper presented in memoriam of Abraham Malherbe, North West University, Potchefstroom, 01 August 2013.

Van Aarde, A.G., 2014a, 'A commemoration of the legacy of Rudolf Bultmann, born 130 years ago', Studia Historiae Ecclesiasticae 40(1), 251-271.

Van Aarde, A.G., 2014b, 'Pragmatic dimensions in parable research and the divine economy of the basileia', paper presented at the 'Religion and Pluralities of Knowledge' conference, University of Groningen, the Netherlands, 01-14th May 2014.

Van Aarde, A.G., 2015, 'The love for the poor neighbour: In memory of her (Mt 26 $6-13)^{\prime}$ ', voordrag gelewer by die 'Perspectives on the Socially Disadvantaged in Early Christianity' konferensie, University of the Free State, 23-24th October 2014.

Weaver, J.B., 2008, 'The noble and good heart: Kalokagathia in Luke's parable of the sower', in C.R. Holladay, P. Gray \& G.R. O'Day (eds.), Scripture and traditions: Essays on early Judaism and Christianity in honor of Carl R. Holladay, pp. 151-172, Brill, Leiden. (Supplements to Novum Testamentum, 129). 